\title{
ALTERNATIF MODEL PENGGUNAAN BUKU SEKOLAH ELEKTRONIK (BSE) BERBASIS PROJECT BASED LEARNING SEBAGAI SALAH SATU SUMBER BELAJAR DI SEKOLAH MENENGAH KEJURUAN
}

\author{
Sutrisno, Eko Supri Murtiono, A.G. Tamrin \\ Prodi. Pendidikan Teknik Bangunan, Jurusan Pendidikan Teknik Kejuruan, FKIP, UNS \\ Kampus UNS Pabelan Jl. Ahmad Yani 200, Surakarta, Tlp (0271)718419 Fax. (0271)716266
}

\begin{abstract}
ABSTRAK
Penggunaan buku sekolah elektronik di SMK disinyalir belum maksimal dan belum dipadukan dengan berbagai model pembelajaran di SMK. Mengingat uji kompetensi di SMK dilaksanakan dengan model berbasis proyek, maka diperlukan suatu model penggunaan buku sekolah elektronik berbasis project based learning sebagai salah satu sumber belajar di SMK. Penelitian ini akan mengungkap dan menemukan tentang kondisi penggunaan buku sekolah elektronik di SMK, kondisi pelaksanaan pembelajaran dengan project based learning di SMK, dan model penggunaan buku sekolah elektronik berbasis project based learning sebagai salah satu sumber belajar di SMK.

Penelitian ini menggunakan metode survey deskriptif dan Focus Group Discussion (FGD) dengan pendekatan kuantitatif dan kualitatif. Pendekatan kuantitatif digunakan untuk menjawab tujuan yang diukur dengan prosentase,yaitu kondisi tentang penggunaan BSE dan Model PBL, sedangkan pendekatan kualitatif digunakan untuk menjawab tujuan yang diukur berdasarkan fenomena/gejala, yaitu model penggunaan BSE berbasis PBL.

Populasi dalam penelitian ini adalah guru-guru pada program studi keahlian Teknik Bangunan di SMK Negeri 2 dan SMK Negeri 5 Surakarta. Sampel penelitian dipilih dengan teknik purposive sampling.

Hasil penelitian yang didapatkan adalah; (1) Kesepadanan antara konsep dengan penggunaan Buku Sekolah elektronik (BSE) dalam proses belajar, didapatkan hasil rata-rata secara keseluruhan adalah 53,4\%. Hal tersebut menunjukkan bahwa penggunaan BSE dalam proses belajar mengajar baru 53,4\% sesuai dengan konsep diadakannya BSE tersebut, (2) Kesepadanan antara konsep dengan penerapan model pembelajaran Project Based Learning (PBL) dalam proses belajar, didapatkan hasil rata-rata secara keseluruhan adalah $74 \%$. Hal tersebut menunjukkan bahwa penerapan model pembelajaran PBL dalam proses belajar mengajar $74 \%$ sesuai dengan konsep dari ketentuan di dalam pelaksaan PBL, dan (3) Alternatif model penggunaan BSE berbasis PBL sebagai salah satu sumber belajar ditinjau dari 4 (empat) aspek, yaitu; (a) Aspek bentuk: berbasis internet, (b)

Aspek materi dasar kejuruan: penguasaan konsep dan prinsip dasar, berbentuk uraian singkat (teori), produk berupa hasil telaah, perhitungan/desain, (c) Aspek materi keahlian kejuruan: pengembangan keterampilan pemecahan masalah kompleks, berbentuk laporan kegiatan (perencanaan dan proses kerja), produk berupa benda nyata, dan (d) Aspek sistem evaluasi: berbasis proses dan produk.
\end{abstract}

Kata Kunci: Buku Sekolah Elektronik, Project Based Learning, Sumber Belajar.

\section{PENDAHULUAN}

\section{Latar Belakang Masalah}

Dunia pendidikan juga tidak bisa mengelak dari perubahan itu, bahkan sudah sewajarnya mengambil peran aktif untuk memanfaatkan TIK demi kemajuan pendidikan. Reformasi pendidikan adalah kuncinya, dan TIK adalah urat nadi yang memperlancar reformasi tersebut. Pendidikan merupakan kunci keberhasilan dan kesuksesan suatu bangsa. Dalam melaksanakan program pendidikan diperlukan peran guru dalam proses pembelajaran agar tercapai tujuan pendidikan. Dalam proses pembelajaran sumber belajar yang ada di lingkungan sekolah atau di luar sekolah dapat dimanfaatkan dengan sebaik-baiknya sebagai sumber belajar alternatif bagi guru dan siswa.
Sumber belajar yang dapat dimanfaatkan salah satunya adalah media BSE, yaitu sumber belajar berupa file yang dapat di unduh melalui internet/buku yang sudah berbentuk buku cetak yang berlebelkan BSE. BSE dapat digunakan guru dan siswa sebagai buku pendamping atau sumber belajar alternatif. Sumber belajar media BSE ini sudah disosialisasikan oleh Depdiknas ke sekolah-sekolah, salah satunya adalah di SMKN yang ada di Kota Surakarta. Oleh karena itu,dunia pendidikan juga perlu bersikap lentur dan adaptif terhadap perubahan. Untuk itulah,sebagai sosok yang berdiri di garda depan dalam dunia pendidikan, guru (pendidik) dituntut untuk kreatif dalam melakukan berbagai inovasi pembelajaran,salah satunya adalah cara memilih sumber belajar yang tepat untuk peserta didiknya. 
Sehingga mempermudah seorang pendidik dalam menyampaikan materi ajarnya.

Buku Sekolah Elektronik (BSE) yang di sediakan oleh Kementerian Pendidikan Nasional saat ini berjumlah Tersedia total 927 buku, terdiri atas: 291 buku SD/MI, 291 buku SMP/MTs, 276 Buku SMA/MA, 204 buku SMK, dan 2 buku Bahasa (Sumber:http://bse.depdiknas.go.id). Namun dalam kenyataannya masih belum maksimal dalam pemanfaatannya di berbagai tingkat pendidikan khususnya di Sekolah Menengah Kejuruan di Surakarta yaitu di SMK N 5 Surakarta dan SMK N 2 Surakarta khususnya di Jurusan Teknik Bangunan. Guru masih menggunakan sumber belajar yang lama dan kurang mengikuti perkembangan zaman khususnya dibidang teknologi informasi dan komunikasi.

Keberadaan BSE yang hadir dalam bentuk PDF yang online di internet atau dalam bentuk cetak merupakan inovasi baru dalam peningkatan kualitas pendidikan di Indonesia . Buku BSE tersedia di situs Buku Sekolah Elektronik dan telah dinilai kelayakan pakainya oleh Badan Standar Nasional Pendidikan (BSNP) dan telah ditetapkan sebagai buku teks pelajaran yang memenuhi syarat kelayakan untuk dapat digunakan dalam pembelajaran. Namun, sampai saat ini penggunaannya belum maksimal dan belum dipadukan dengan berbagai model pembelajaran di SMK. Mengingat uji kompetensi di SMK dilaksanakan dengan model berbasis proyek, maka diperlukan suatu alternatif model penggunaan buku sekolah elektronik berbasis project based learning sebagai salah satu sumber belajar di SMK.

\section{Rumusan Masalah}

Rumusan masalah yang akan dijawab dalam penelitian ini adalah;

1. Bagaimana kondisi penggunaan buku sekolah elektronik dalam pelaksanaan pembelajaran kelompok produktif di SMK?

2. Bagaimana pelaksanaan model pembelajaran project based learning kelompok produktif di SMK?

3. Bagaimana alternatif model penggunaan Buku Sekolah Elektronik berbasis Project Based Learning dalam pelaksanaan pembelajaran kelompok produktif di SMK?

\section{Kajian Pustaka Yang Sudah Dilaksanakan} Buku Sekolah Elektronik (BSE)

Buku merupakan salah satu sarana penting dalam upaya meningkatkan mutu pendidikan. Salah satu permasalahan perbukuan dalam era otonomi daerah dewasa ini adalah ketersediaan buku yang memenuhi standar nasional pendidikan dengan harga murah yang dapat dijangkau oleh masyarakat luas. Untuk mengatasi hal tersebut, Departemen Pendidikan Nasional telah membeli hak cipta buku teks pelajaran dari penulis/penerbit. Selanjutnya bukubuku tersebut disajikan dalam bentuk buku elektronik(e-book) dengan nama Buku Sekolah Elektronik (BSE).

Tujuan dari diadakannya BSE adalah:

1. Menyediakan sumber belajar alternatif bagi siswa.

2. Merangsang siswa untuk berpikir kreatif dengan bantuan teknologi informasi dan komunikasi.

3. Memberi peluang kebebasan untuk menggandakan, mencetak, memfotocopy, mengalihmediakan, dan/atau memperdagangkan BSE tanpa prosedur perijinan, dan bebas biaya royalti sesuai dengan ketentuan yang diberlakukan Menteri.

4. Memberi peluang bisnis bagi siapa saja untuk menggandakan dan memperdagangkan dengan proyeksi keuntungan $15 \%$ sesuai dengan ketentuan yang berlaku

Keberadaan BSE ditujukan untuk siswa, guru, dan seluruh masyarakat Indonesia. BSE,baik dalam bentuk buku maupun rekaman cakram (CD/DVD) dapat digandakan dan diperdagangkan dengan ketentuan tidak melebihi Harga Eceran Tertinggi (HET) yang ditetapkan oleh Menteri Pendidikan Nasional dan memenuhi syarat serta ketentuan yang berlaku.

\section{Sumber Belajar}

Sumber belajar mencakup apa saja yang dapat digunakan untuk membantu tiap orang untuk belajar dan manampilkan kompetensinya. Sumber belajar meliputi, pesan, orang, bahan, alat, teknik, dan latar (AECT 1994), Menurut Dirjen Dikti (1983: 12), sumber belajar adalah segala sesuatu dan dengan mana seseorang mempelajari sesuatu. Degeng (1990: 83) menyebutkan sumber belajar mencakup semua sumber yang mungkin dapat dipergunakan oleh si-belajar agar terjadi prilaku belajar. Dalam proses belajar komponen sumber belajar itu mungkin dimanfaatkan secara tunggal atau secara kombinasi, baik sumber belajar yang direncanakan maupun sumber belajar yang dimanfaatkan.

Sumber belajar yang beraneka ragam disekitar kehidupan peserta didik, baik yang didesain maupun non desain belum dimanfaatkan 
secara optimal dalam pembelajaran. Sebagian besar guru kecenderugan dalam pembelajaran memanfaatkan buku teks dan guru sebagai sumber belajar utama. Ungkapan ini diperkuat oleh Parcepal dan Ellington (1984), bahwa dari sekian banyaknya sumber belajar hanya buku teks yang banyak dimanfaatkan. Hal senada juga diperkuat oleh suatu hasil penelitian para dosen IKIP Semarang mengenai kebutuhan informasi, yang menyatakan bahwa banyak sumber belajar diperpustakaan yang belum dikenal dan belum diketahui penggunaannya. Keadaan ini diperparah pemanfaatan buku sebagai sumber belajar juga masih bergantung pada kehadiran guru, kalau guru tidak hadir maka sumber belajar lain termasuk bukupun tidak dapat dimanfaatkan oleh peserta didik. Oleh karena itu kehadiran guru secara fisik mutlak diperlukan, disisi lain sebenarnya banyak sumber belajar disekitar kehidupan peserta didik yang dapat dimanfaatkan untuk pembelajaran.

\section{Model Project-Based Learning}

Pendekatan Pembelajaran Berbasis Proyek (project-based learning) ini merupakan adaptasi dari pendekatan pembelajaran berbasis masalah (problem-based learning) yang awalnya berakar pada pendidikan medis (kedokteran). Pendidikan medis menaruh perhatian besar terhadap fenomena praktisi medis muda yang memiliki pengetahuan faktual cukup tetapi gagal menggunakan pengetahuannya saat menangani pasien sungguhan (Maxwell, Bellisimo, \& Mergendoller, 1999). Setelah melakukan pengkajian bagaimana tenaga medis dididik, pendidikan medis mengembangkan program pembelajaran yang men-cemplung-kan siswa ke dalam skenario penanganan pasien baik simulatif ataupun sungguhan. Proses ini kemudian dikenal sebagai pendekatan problem-based learning. Kini, problem-based learning diterapkan secara luas pada pendidikan medis di negara-negara maju.

Karakteristik permasalahan pada pendidikan medis tersebut mirip dengan permasalahan pada pendidikan teknologi dan kejuruan. Tamatan pendidikan teknologi (dan kejuruan) belum siap memasuki lapangan kerja atau bahkan gagal di tempat kerja, meskipun pengetahuan faktual telah cukup diperoleh di sekolah. Berdasarkan pengalaman pada pendidikan medis, pendekatan problem-based learning diadaptasi menjadi model project-based learning untuk pendidikan teknologi dan kejuruan, terutama program kompetensi produktif. Keduanya menekankan lingkungan belajar siswa aktif, kerja kelompok (kolaboratif), dan teknik evaluasi otentik (authentic assessment). Perbedaannya terletak pada perbedaan objek. Kalau dalam problem-based learning pebelajar lebih didorong dalam kegiatan yang memerlukan perumusan masalah, pengumpulan data, dan analisis data (berhubungan dengan proses diagnosis pasien); maka dalam project-based learning pebelajar lebih didorong pada kegiatan desain: merumuskan job, merancang (designing), mengkalkulasi, melaksanakan pekerjaan, dan mengevaluasi hasil. Seperti didefinisikan oleh Buck Institute fo Education (1999), bahwa belajar berbasis proyek memiliki karakteristik: (a) pebelajar membuat keputusan, dan membuat kerangka kerja, (b) terdapat masalah yang pemecahannya tidak ditentukan sebelumnya, (c) pebelajar merancang proses untuk mencapai hasil, (d) pebelajar bertanggungjawab untuk mendapatkan dan mengelola informasi yang dikumpulkan, (e) melakukan evaluasi secara kontinu, (f) pebelajar secara teratur melihat kembali apa yang mereka kerjakan, (g) hasil akhir berupa produk dan dievaluasi kualitasnya, dan (i) kelas memiliki atmosfer yang memberi toleransi kesalahan dan perubahan.

\section{Kerangka Berfikir}

Berdasarkan uraian pada tinjauan pustaka, maka beberapa hal yang menjadi kerangka berpikir dalam penelitian ini adalah;

1. Dalam kaitannya dengan penggunaan buku sekolah elektronik, perlu dilakukan analisis kesepadanan antara konsep dengan pelaksanaan penggunaan buku sekolah elektronik dalam proses belajar,

2. Berkaitan dengan model Project Based learning, perlu dilakukan analisis kesepadanan antara konsep dengan pelaksanaan model project based learning dalam proses belajar,

3. Berdasarkan hasil analisis kesepadanan antara konsep dengan pelaksanaan penggunaan buku sekolah elektronik dan penerapan model project based learning, perlu dilakukan analisis keterpaduan, sehingga akan muncul alternatif model penggunaan BSE berbasis project learning di SMK.

Kerangka berpikir tersebut dapat digambarkan dalam diagram alir seperti berikut: 


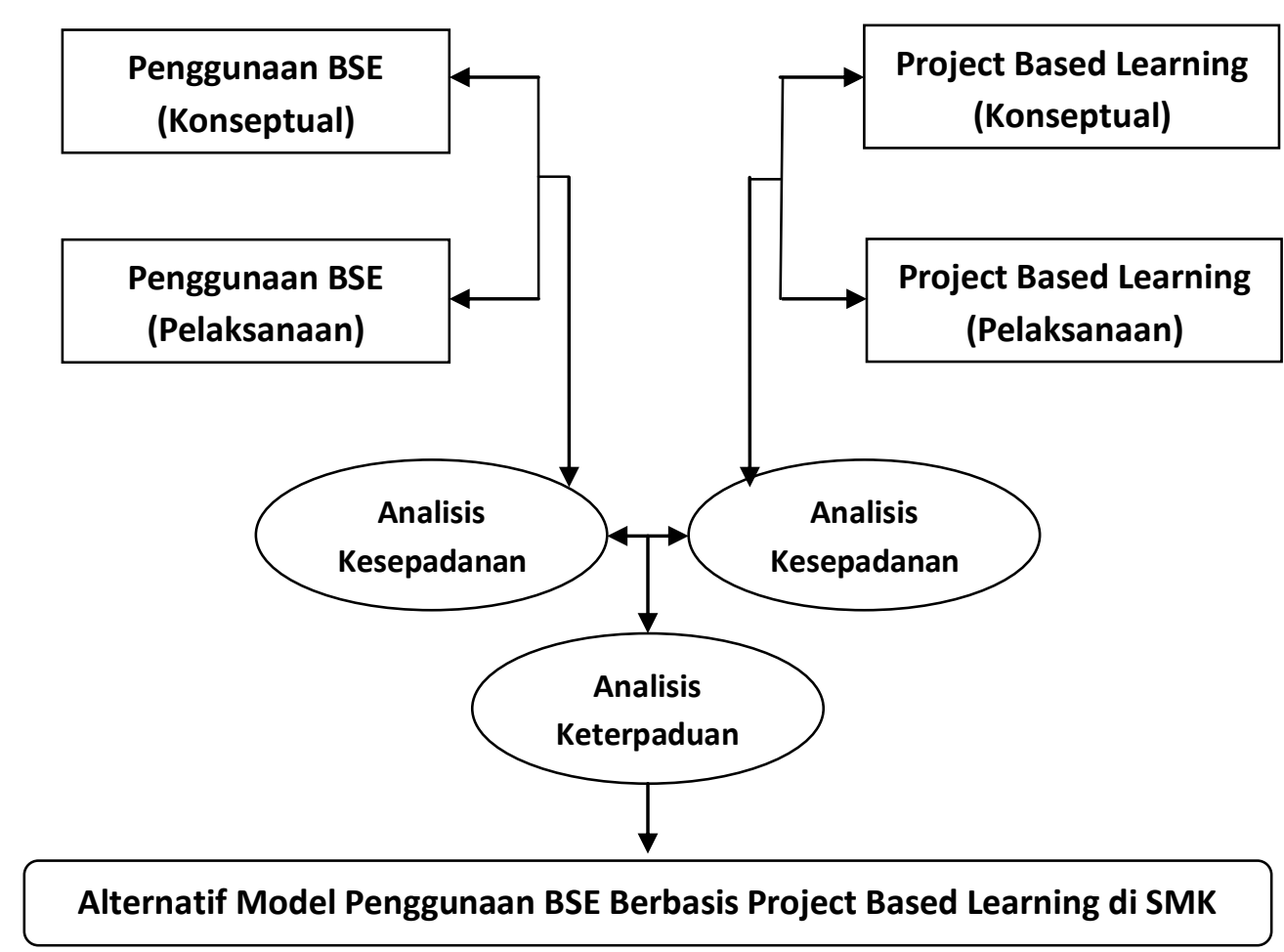

Gambar 1. Diagram Alir Kerangka Berpikir

\section{METODE PENELITIAN}

\section{Tempat dan Waktu Penelitian}

Penelitian ini merupakan penelitian yang menganalisis data kesepadanan antara konsep dengan pelaksanaan penggunaan BSE dan model pembelajaran PBL serta alternatif model penggunaan BSE berbasis PBL yang merupakan keterpaduan hasil antara konsep dengan pelaksanaan penggunaan BSE dan model pembelajaran PBL. Tempat penelitian dilaksanakan di 2 (dua) tempat, yaitu;

1. SMKN 2 dan SMKN 5 Surakarta, untuk survey secara deskriptif tentang kesepadanan antara konsep dengan pelaksanaan penggunaan BSE dan model pembelajaran PBL,

2. Kampus JPTK FKIP Pabelan, untuk menemukan alternatif model penggunaan BSE berbasis PBL.

Waktu dan pelaksanaan kegiatan dalam penelitian ini dilaksanakan pada bulan
Januari 2012 sampai dengan bulan Nopember 2012.

\section{Pendekatan Penelitian}

Penelitian ini menggunakan metode survey deskriptif dan Focus Group Discussion (FGD) dengan pendekatan kuantitatif dan kualitatif. Pendekatan kuantitatif digunakan untuk menjawab tujuan yang diukur dengan prosentase, yaitu kondisi tentang penggunaan BSE dan pelaksanaan model pembelajaran PBL, sedangkan pendekatan kualitatif digunakan untuk menjawab tujuan yang diukur berdasarkan fenomena/gejala, yaitu alternatif model penggunaan BSE berbasis PBL.

\section{Populasi dan Sampel}

Populasi dalam penelitian ini adalah semua guru dan semua buku sekolah elektronik pada bidang studi keahlian Teknologi dan Rekayasa. Untuk lebih menjamin kedalaman hasil penelitian, maka dilakukan sampling. Sampel dipilih dengan teknik purposive sampling, yaitu penetapan sampel berdasarkan 
tujuan penelitian. Yang ditetapkan sebagai sampel adalah guru-guru pada program studi keahlian Teknik Bangunan, dan buku sekolah elektronik yang ditetapkan sebagai sampel adalah buku sekolah elektronik pada program studi keahlian Teknik Bangunan.

\section{Sumber Data Penelitian}

Sumber data penelitian dikelompokkan ke dalam dua bagian sebagai berikut.

1. Data primer, berupa hasil kesepadanan antara konsep dengan pelaksanaan penggunaan BSE dan model pembelajaran PBL,

2. Informan, berupa individu dan kelompok individu yang memiliki informasi terkait dengen penelitian yang dilakukan. Informan sebagai sumber data dapat dikelompokkan ke dalam duajenis, yaitu;

a. Informan individu merupakan nara sumber, yaitu dosen profesional yang memiliki kompetensi terhadap konsep penggunaan BSE dan model pembelajaran PBL,

b. Informan kelompok individu merupakan penanggap yang terdiri dari kelompok homogen, yaitu para guru dan praktisi pada kompetensi keahlian teknik bangunan di SMKN 2 dan SMKN 5 Surakarta.

\section{Teknik Pengumpulan Data}

Teknik pengumpulan data yang dilakukan dibedakan menjadi 2 jenis teknik pengumpulan, yaitu;

\section{Data Kesepadanan Konsep dengan} Pelaksanaan Penggunaan BSE dan Model Pembelajaran PBL

Data kesepadanan antara konsep dengan pelaksanaan penggunaan BSE dan kesepadanan antara konsep dengan pelaksanaan penerapan model pembelajaran PBL dikumpulkan menggunakan lembar observasi. Lembar observasi yang digunakan adalah lembar observasi terstandar berdasarkan ketentuan yang sudah tercantum dalam konsep penggunaan BSE dan konsep penerapan PBL.

\section{Data Alternatif Model Penggunaan BSE Berbasis PBL}

Sesuai dengan tujuan penelitian, setelah kesepadanan antara konsep dengan penggunaan BSE dan PBL ditemukan, maka langkah selanjutnya adalah menemukan alternatif model penggunaan BSE berbasis PBL. Pengumpulan data dilakukan dengan teknik FGD (Focus Group Discussion), yaitu suatu diskusi yang dilakukan secara sistematis dan terarah mengenai suatu isu atau masalah tertentu. Irwanto (2006: 1-2) mendefinisikan FGD sebagai suatu proses pengumpulan data dan informasi yang sistematis mengenai suatu permasalahan tertentu yang sangat spesifik melalui diskusi kelompok.

\section{Validitas dan Reliabilitas Data}

1. Data Kesepadanan Konsep dengan Pelaksanaan Penggunaan BSE dan Model Pembelajaran PBL

Untuk menjamin bahwa data yang diperoleh terbebas dari unsur bias, maka dilakukan uji validitas dengan teknik validitas konstruk, yaitu menelaah kembali konstruk dari pernyataan-pernyataan pada lembar observasi. Teknik ini dipilih karena lembar observasi yang digunakan adalah lembar observasi terstandar yang merupakan observasi dari konsep penggunaan BSE dan konsep dari penerapan model pembelajaran PBL.

Untuk menjamin keajegan data, dilakukan uji reliabilitas dengan teknik keakuratan dan interrater (Suwardi Endaswara, 2011: 164). Keakuratan adalah penyesuaian antara hasil penelitian dengan kajian pustaka yang telah dirumuskan, sementara interrater, yaitu perbandingan data yang dikumpulkan peneliti dengan peneliti lain, dalam hal ini adalah data yang dikumpulkan oleh 2 orang anggota peneliti lainnya.

\section{Data Alternatif Model Penggunaan BSE Berbasis PBL}

Data alternative model penggunaan BSE berbasis PBL diperoleh melalui FGD, sehingga data yang diperoleh adalah data individu sekaligus kelompok. Untuk menjamin validitas dan reliabilitas data yang diperoleh, maka dilakukan dengan teknik tim, Iwan Awaludin (2011) memberikan alasan tentang teknik tim, yaitu semua pekerjaan, mulai dari mengumpulkan data, membahas hasil, mencari topik yang penting dalam transkrip, membahas kembali topik-topik itu, sampai menuliskan laporan hasil FGD dilakukan secara tim untuk menghindari pendapat subjektif pribadi. Dengan teknik tim, maka laporan hasil FGD bisa mendekati keutuhan karena berbagai pandangan saling melengkapi. Teknik tim diterapkan dengan melibatkan 2 orang anggota peneliti.

\section{Teknik Analisis Data}

\section{Analisis Data Kesepadanan Konsep dengan Pelaksanaan Penggunaan BSE dan Model Pembelajaran PBL \\ Data kesepadanan konsep dengan pelaksanaan penggunaan BSE dan model}


pembelajaran PBL dianalisis secara kuantitatif dengan teknik statistik deskriptif. Teknik statistik deskriptif yang diterapkan yaitu dengan menghitung prosentase kesesuaian dan prosentase ketidaksesuaian antara konsep dengan penggunaan BSE dan antara konsep dengan penerapan model PBL.

\section{Analis Data Alternatif Model Penggunaan BSE Berbasis PBL}

Secara umum, teknik analisis data yang digunakan adalah menggunakan analisis data penelitian kualitatif model interaktif dari Miles danHubermen (1992: 16-20), yang terdiri dari tiga tahap, yaitu : (a). Tahap reduksi data (b). Tahap penyajian data (c). Tahap penarikan kesimpulan dan verifikasi data.Analisis data dilakukan pada saat pengumpulan data berlangsung, dan setelah selesai pengumpulan data dalam periode tertentu, (Sugiono, 2009:246).

Berdasarkan ketetapan tersebut, maka model analisis interaktif yang diterapkan dapat digambarkan dalam bagan berikut.

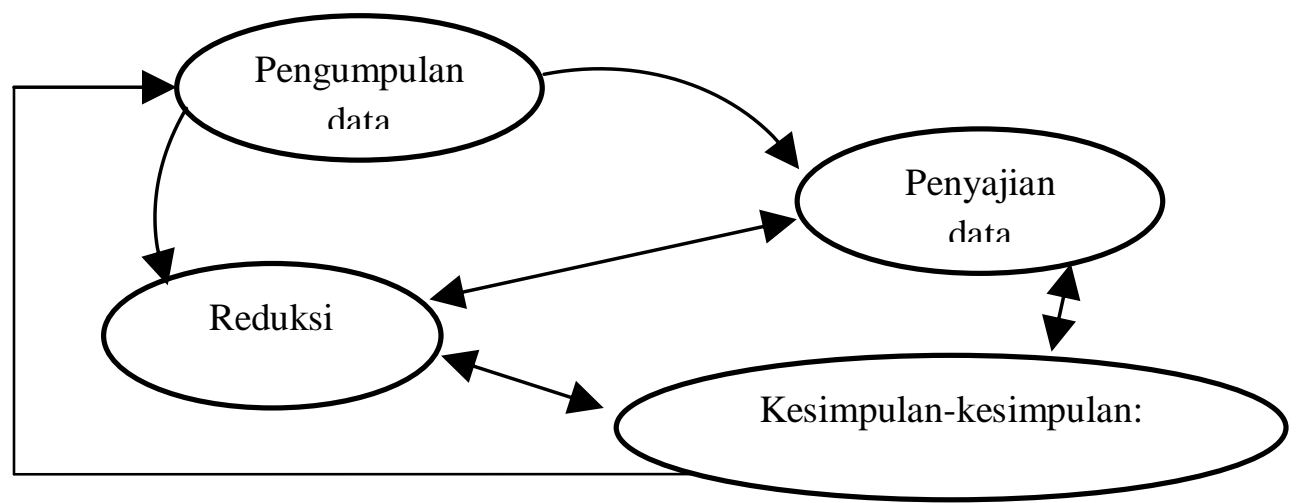

Gambar 2. Komponen-komponen Analis Data Model Interaktif (Sumber: Miles dan Huberman, 1992: 20)

\section{HASIL DAN PEMBAHASAN}

Sesuai dengan tujuan penelitian yang hendak dicapai, FGD yang dilakukan difokuskan untuk menemukan alternatif model penggunaan BSE berbasis PBL. Analisis yang dilakukan dalam FGD menggunakan beberapa acuan yang digunakan sebagai dasar untuk menemukan alternative model pemanfaatan BSE berbasis PBL, yaitu;

1. Hasil kesepadanan antara konsep dengan penggunaan BSE dalam proses belajar mengajar,
2. Hasil kesepadanan antara konsep dengan penerapan model pembelajaran Project Based Learning,

3. Tinjauan keterpaduan antara kesepadanan penggunaan BSE dengan kesepadanan penerapan PBL yang ditinjau dari sisi bentuk, materi dasar kejuruan, materi keahlian kejuruan, dan teknik evaluasi.

Berdasarkan ketentuan dalam FGD dan acuan yang dijadikan dasar dalam FGD, maka proses pelaksanaan analisis FGD dapat digambarkan dalam bagan berikut. 


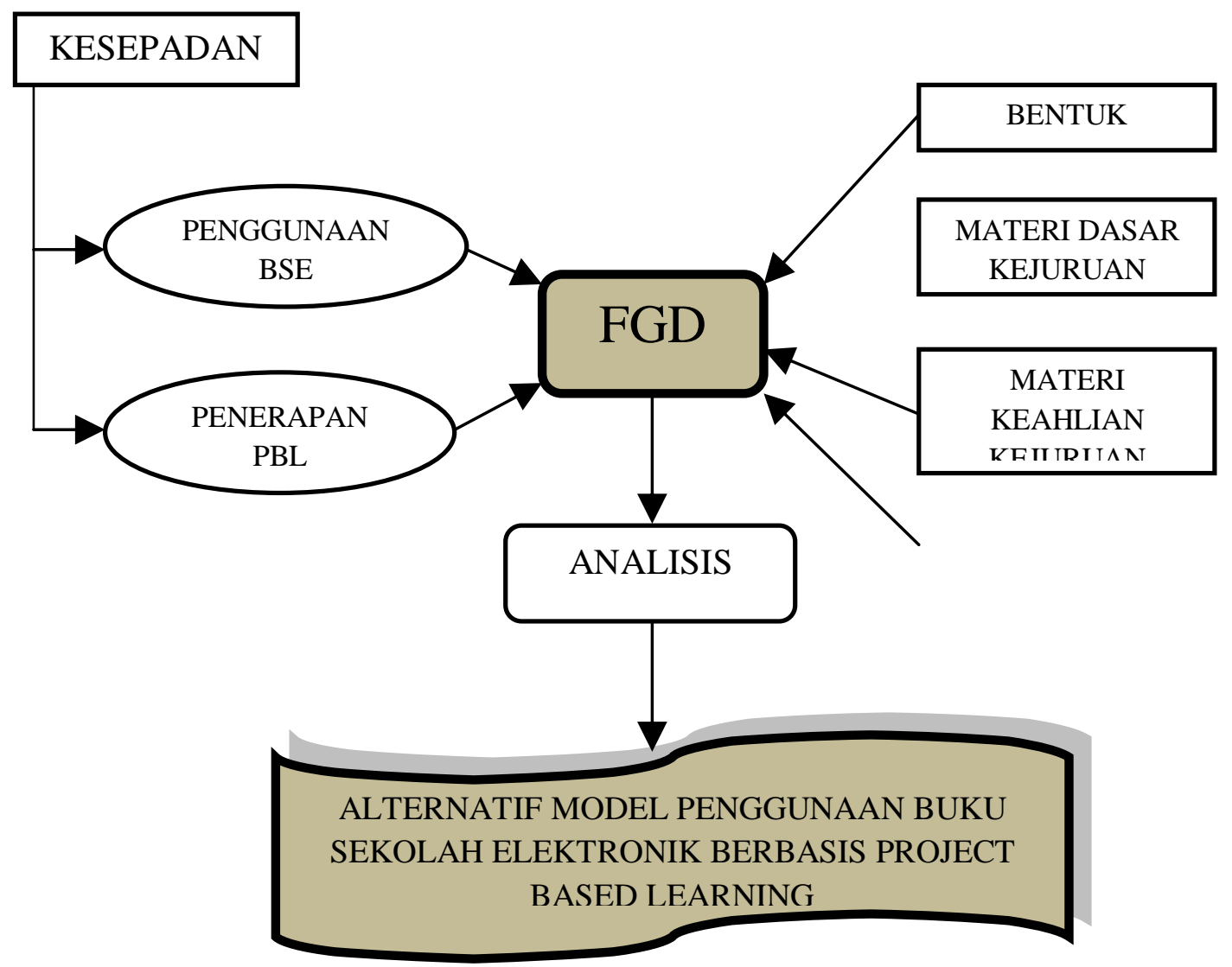

Gambar 3. Proses Analisis dalam FGD

\section{KESIMPULAN}

1. Dari hasil analisis kesepadanan antara konsep dengan penggunaan Buku Sekolah elektronik (BSE) dalam proses belajar, didapatkan hasil rata-rata secara keseluruhan adalah 53,4\%. Hal tersebut menunjukkan bahwa penggunaan BSE dalam proses belajar mengajar baru $53,4 \%$ sesuai dengan konsep diadakannya BSE tersebut.

2. Dari hasil analisis kesepadanan antara konsep dengan penerapan model pembelajaran Project Based Learning (PBL) dalam proses belajar, didapatkan hasil ratarata secara keseluruhan adalah $74 \%$. Hal tersebut menunjukkan bahwa penerapan model pembelajaran PBL dalam proses belajar mengajar $74 \%$ sesuai dengan konsep dari ketentuan di dalam pelaksaan PBL.

3. Alternatif model penggunaan BSE berbasis PBL sebagai salah satu sumber belajar ditinjau dari 4 (empat) aspek, yaitu;
a. Aspek bentuk: berbasis internet,
b. Aspek materi dasar kejuruan: penguasaan konsep dan prinsip dasar,

berbentuk uraian singkat (teori), produk berupa hasil telaah, perhitungan/desain,

c. Aspek materi keahlian kejuruan: pengembangan keterampilan pemecahan masalah kompleks, berbentuk laporan kegiatan (perencanaan dan proses kerja), produk berupa benda nyata

d. Aspek sistem evaluasi: berbasis proses dan produk.

\section{DAFTAR PUSTAKA}

AECT. 1977. Selecting Media for Learning. Washington DC: Association for Education Communication and Technology.

Arif Sadiman, S, Raharjo, R, Anung Haryono. 1986. Media Pendidikan. Jakarta: CV. Rajawali.

Barbara B. Seels, Rita C. Richey. 1994. Instructional Technology: The definition and Domains of the Field. Washington, DC: Associations and Technology. 
Departemen Pendidikan dan Kebudayaan. 1983. Teknologi Instruksional. Jakarta: Ditjen Dikti, Proyek Pengembangan Institusi Pendidikan Tinggi.

Depdiknas. 2006. Permendiknas Nomor 22 Tahun 2006 tentang Standar Isi. Jakarta: Depdiknas

Depdiknas. 2006. Permendiknas Nomor 23 Tahun 2006 tentang Standar Kompetensi Lulusan. Jakarta: Depdiknas

Depdiknas. 2007. Permendiknas Nomor 41 Tahun 2007 tentang Standar Proses. Jakarta: Depdiknas

Dirjen Mandikdasmen. 2008. Keputusan Dirjen Mandikdasmen Nomor 251/C/KEP/MN/2008 tentang Spektrum Keahlian Pendidikan Menengah Kejuruan. Jakarta: Dirjen Mandikdasmen.

Ditpsmk. 2009. Bimbingan Teknis Implementasi KTSP di SMK. Jakarta: Ditpsmk

Gagne, R.M., \& Briggs, L.J., 1979. Principles of Instructional Design, New York: Holt, Renerhart and Winston.

H. B. Sutopo. 2006. Metodologi Penelitian Kualitatif. Surakatra: Universitas Sebelas Maret.

Henry \& Perceval, Elington, Fred. 1984. A Handbook of Educational technology. London: Kogan Page Ltd. Pentoville Road.

Irwanto. 1998. Focus Group Discussion (FGD) Sebuah Pengantar Praktis. Jakarta: PKPM Unika Atmajaya

Iwan Awaladuddin Yusuf. 2011. Memahami Focus Group Discussion (FGD. http://bincangmedia.wordpress.com/2011 /03/28/relasi-media-dan-konsumtivismepada-remaja/Diunduh 25 September 2011

Karwono. 2007. Pemanfaatan Sumber Belajar dalam Upaya Peningkatan Kualitas dan hasil Pembelajaran (Makalah). MetroLampung

Lexy J. Moleong. 2011. Motodologi Penelitian Kualitatif. Bandung: Rosda Karya.

Miles, Matthew B. dan Huberman, A. Michael.1992. Analisi Data Kualitatif(Penerjemah Tjetjep Rohendi Rohidi). Jakarta: UI-Press.

Muhammad Nuh. 2010. Pengantar BSE. Jakarta: Kepmendiknas

N.A. Suparwoto. 2009. Mengembangkan Bahan Ajar dengan Menyusun Modul (Makalah). Kebumen.

Regeluth, C.M. 1983. Instructional Design Theories and Models: An Overview $f$ their Current Status. Hillsdale, N.J: Lawrence Erlbaum Associates, 3-36.

Republik Indonesia. 2003. Undang-undang Nomor 20 Tahun 2003 tentang Sisdiknas. Jakarta: Sekretariat Negara

Sugiyono. 2009. Metode Penelitian Kuantitatif, Kualitatif, dan $R$ \& D. Bandung: CV Alfabeta.

Suthardhi, SD. 1981. Pemanfaatan Alam Sekitar sebagai Sumber Belajar Anak. Analisis Pendidikan. Depdikbud. Jakarta Tahun II. (1) 146-159.

Suwardi Endraswara. 2011. Metodologi Penelitian Sastra. Yogyakarta: CAPS.

http://bojadd-twicelawyer.blogspot.com 